Int. J. Electrochem. Sci., 14 (2019) 9960 - 9973

International Journal of

ELECTROCHEMICAL

SCIENCE

$\underline{\text { www.electrochemsci.org }}$

\title{
Effect of Thiosulfate on Corrosion Behavior and Passive Films of Duplex Stainless Steel 2205 in Chloride Solutions
}

\author{
Jiantao Zhang, Xiaojun $\mathrm{Hu}^{*}$, Kuochih Chou \\ State Key Laboratory of Advanced Metallurgy, University of Science and Technology Beijing, Beijing \\ 100083, P.R. China \\ *E-mail: huxiaojun@ustb.edu.cn
}

doi: $10.20964 / 2019.10 .53$

Received: 25 June 2019 / Accepted: 6 August 2019 / Published: 30 August 2019

The effect of $\mathrm{S}_{2} \mathrm{O}_{3}^{2-}$ on the corrosion behavior and passive films of duplex stainless steel 2205 in a $\mathrm{Cl}^{-}$-containing environment was investigated by potentiodynamic polarization, electrochemical impedance spectroscopy, Mott-Schottky measurements and XPS composition analysis. The results show that the addition of $\mathrm{S}_{2} \mathrm{O}_{3}^{2-}$ decreased the pitting potential of duplex stainless steel 2205 in $\mathrm{Cl}^{-}$-containing solutions. The corrosion resistance of passive films was influenced by the concentration of $\mathrm{S}_{2} \mathrm{O}_{3}^{2-}$ in $\mathrm{Cl}^{-}$-containing solutions, but the exhibited n-type and p-type semiconductor characteristics were not affected. The modified stability and the variation in donor and acceptor densities of the passive film with the concentration of $\mathrm{S}_{2} \mathrm{O}_{3}^{2-}$ were detected. The primary components of the passive films on duplex stainless steel 2205 in a $\mathrm{Cl}^{-}-\mathrm{S}_{2} \mathrm{O}_{3}^{2-}$ solution were $\mathrm{Cr}$-oxides and $\mathrm{Fe}$-oxides or hydroxides with small amounts of $\mathrm{Ni}$ and Mo oxides.

Keywords: duplex stainless steel, $\mathrm{Cl}^{-}, \mathrm{S}_{2} \mathrm{O}_{3}^{2-}$, corrosion behavior, passive film.

\section{$\underline{\text { FULL TEXT }}$}

(C) 2019 The Authors. Published by ESG (www.electrochemsci.org). This article is an open access article distributed under the terms and conditions of the Creative Commons Attribution license (http://creativecommons.org/licenses/by/4.0/). 